\title{
PENGARUH KARAKTERISTIK PEKERJAAN, IKLIM ORGANISASI DAN KEPUASAN KERJA TERHADAP KINERJA KARYAWAN
}

\section{EFFECT OF JOB CHARACTERISTICS, ORGANIZATIONAL CLIMATE AND WORK SATISFACTION ON EMPLOYEE PERFORMANCE}

\author{
Prima Aprilyani Rambe \\ Fakultas Ekonomi Universitas Maritim Raja Ali Haji \\ prima_aprilyani@gmail.com
}

\begin{abstract}
Abstrak
Penelitian ini dilakukan untuk mengetahui: pertama, apakah Karakteristik Pekerjaan, Iklim Organisasi dan Kepuasan Kerja memiliki pengaruh parsial dan simultan terhadap kinerja PT. X Batam. Populasi dalam penelitian ini berjumlah 70 pegawai tetap PT. X Batam. Dimana sampling menggunakan teknik yang digunakan sensus dan 70 kuesioner sebagai random sampling secara acak diberikan kepada responden segala sesuatu kembali ke 100\%, dimana metode penelitian yang digunakan adalah explanatory survey dengan menggunakan alat analisis data Regresi. Dari hasil analisis menunjukkan bahwa: hipotesis yang dirancang dan dibangun berdasarkan kerangka teoritis dan kerangka kerja. Hasil penelitian menunjukkan bahwa baik secara parsial dan simultan pengaruh signifikan dimana nilai koefisien untuk variabel karakteristik pekerjaan dan kepuasan kerja sedangkan nilai negatif dinilai variabel iklim kerja positif itu tercermin dalam persamaan regresi linier berganda sebagai berikut: $Y=19803-0.018 X 1+0.5626 X 2-0.022 X 3$. Studi ini melibatkan karakteristik pekerjaan, Iklim Organisasi dalam studi peningkatan kinerja organisasi bagi para manajer karyawan praktisi. Secara teoritis hal ini karena ketiga variabel tersebut akan meningkatkan kinerja karyawan pada PT. X Batam. Hasil penelitian ini akan diaplikasikan dan dijadikan masukan dalam pengelolaan PT. Snepac untuk menjadi referensi dalam kebijakan perencanaan SDM terutama studi yang berkaitan dengan Karakteristik Pekerjaan, Iklim Organisasi, Kepuasan Kerja dan Kinerja.
\end{abstract}

\section{Kata kunci: Karakteristik Pekerjaan, Iklim Organisasi, Kepuasan Kerja, Kinerja Karyawan}

\begin{abstract}
This study was conducted to determine: first, whether the Job Characteristics, Organizational Climate and Job Satisfaction has a partial effect on the performance and simultaneously to the PT. X Batam. The population in this study are all numbered 70 permanent employees of PT. X Batam. Where sampling using a technique that is used census and 70 questionnaires as random sampling randomly given to respondents everything back to $100 \%$, which research method used is explanatory survey by using a data analysis tool Regression. From the results of the analysis show that: a hypothesis which was designed and built based on the theoretical framework and the framework. The results show that both partial and simultaneous significant influence where the value of the coefficient for the variable characteristics of employment and job satisfaction while the negative worth valued positive work climate variables it is reflected in the multiple linear regression equation as follows: $Y=$ $19803-0.018 X 1+0.5626 X 2-0.022 X 3$. This study involves the characteristics of the job, Organizational Climate in the study of organizational performance improvement for practitioners employee managers. Theoretically this is because these three variables will improve the performance of employees at PT. X Batam. The results of this research will be applied and make an input into the management of PT. X Batam to become a reference in HR planning policies especially studies related to Job Characteristics, Organizational Climate, Job Satisfaction and Performance.
\end{abstract}

Keywords: Job Characteristics, Organizational Climate, Job Satisfaction, Employee Performance

\section{PENDAHULUAN}

PT. X Batam sangat membutuhkan Sumber Daya Manusia yang handal yang dapat menjalankan tugas utama sebagai ujung tombak pengelolaan kesehatan masyarakat di 
propinsi kepri. Sejalan dengan upaya-upaya yang dilakukan, maka kinerja pegawai memiliki peran yang sangat penting untuk mencapai visi, misi dan tujuan PT. X Batam. Kinerja pegawai merupakan tolak ukur untuk mengetahui sejauh mana pegawai telah melaksankan tugas dan tanggungjawabnya sesuai dengan standar yang diharapkan. Dalam rangka meningkatkan kinerja pegawai, organisasi atau institusi harus menyelaraskan antara tujuan organisasi dengan tujuan pribadi setiap pegawai. Organisasi harus memahami kebutuhan setiap pegawainya sehingga pegawai merasa nyaman dan puas dalam bekerja. Terpenuhinya segala kebutuhan pegawai akan memberikan rasa puas dalam bekerja sehingga akan timbul suatu kesadaran dan tanggung jawab pegawai untuk menyelesaikan setiap tugas atau pekerjaannya. Sementara itu kepuasan kerja pegawai dapat dipengaruhi oleh beberapa faktor baik yang berkaitan dengan diri pegawai itu sendiri (seperti kecerdasan, kemampuan/skill, umur, pendidikan, pengalaman kerja dan sebagainya) dan faktor-faktor yang berasal dari luar diri pegawai (seperti: jenis pekerjaan, struktur organisasi, pangkat, promosi, dan sebagainya).

Kepuasan kerja merupakan faktor penting yang mempengaruhi kepuasan hidup pekerja, karena sebagian besar waktunya digunakan untuk bekerja. Dengan terpenuhinya kebutuhan-kebutuhan tersebut maka para karyawan akan merasa dihargai keberadaannya. Hasil positif yang akan diperoleh adalah meningkatnya tingkat kinerja individual. Penelitian yang dilakukan oleh Maryani dan Supomo (2006: 4) mengenai pengaruh kepuasan kerja terhadap kinerja individual menyimpulkan bahwa terdapat hubungan yang signifikan antara kepuasan kerja terhadap kinerja individual. Kepuasan kerja seorang karyawan terhadap karakteristik pekerjaan, sikap dan kemampuan atasan, dukungan dan kerja sama rekan sekerja, besarnya kompensasi, dan kesempatan untuk promosi merupakan faktor penting dalam memotivasi karyawan untuk meningkatkan kinerjanya. Dengan kata lain, terciptanya kepuasan kerja seorang karyawan terhadap perusahaan, secara otomatis akan mendorong mereka untuk meningkatkan baik kualitas maupun kuantitas pekerjaannya. Hal ini berarti kepuasan kerja yang dirasakan karyawan akan meningkatkan kinerja secara individual yang secara tidak langsung akan berdampak pada kinerja perusahaan secara keseluruhan.

\section{Rumusan Masalah}

Berdasarkan latar belakang di atas maka dapat ditetapkan rumusan masalah penelitian sebagai berikut:

1. Apakah karateristik pekerjaan berpengaruh secara parsial terhadap kinerja pegawai PT. X Batam. 
2. Apakah iklim organisasi berpengaruh langsung terhadap kinerja pegawai PT. X Batam .

3. Apakah kepuasan kerja berpengaruh langsung terhadap kinerja pegawai PT. X Batam.

4. Apakah karateristik pekerjaan ,Iklim Organisasi dan Kepuasan Kerja berpengaruh secara simultan terhadap kinerja pegawai i PT. X Batam.

\section{Tujuan Penelitian}

Sesuai dengan perumusan masalah di atas, tujuan yang ingin dicapai dalam penelitian ini adalah sebagai berikut:

1. Untuk mengetahui apakah karateristik pekerjaan berpengaruh secara parsial terhadap kinerja pegawai PT. X Batam.

2. Untuk mengetahui apakah iklim organisasi berpengaruh langsung terhadap kinerja pegawai PT. X Batam .

3. Untuk mengetahui apakah kepuasan kerja berpengaruh langsung terhadap kinerja pegawai PT. X Batam.

4. Untuk mengetahui apakah karateristik pekerjaan ,Iklim Organisasi dan Kepuasan Kerja berpengaruh secara simultan terhadap kinerja pegawai i PT. X Batam.

\section{Kerangka Teori}

\section{Karakteristik Pekerjaan}

Lodahl dan Kejner (dalam Cohen, 2007) mendefinisikan keterlibatan kerja (Job Involvement) sebagai internalisasi nilai-nilai tentang kebaikan pekerjaan atau pentingnya pekerjaan bagi keberhargaan seseorang. Keterlibatan kerja sebagai tingkat sampai sejauh mana performansi kerja seseorang mempengaruhi harga dirinya dan tingkat sampai sejauh mana seseorang secara psikologis mengidentifikasikan diri terhadap pekerjaannya atau pentingnya pekerjaan dalam gambaran diri totalnya. Individu yang memiliki keterlibatan yang tinggi lebih mengidentifikasikan dirinya pada pekerjaannya dan menganggap pekerjaan sebagai hal yang sangat penting dalam kehidupannya. Brown (dalam Muchinsky, 2007) mengatakan bahwa keterlibatan kerja (Job Involvement) merujuk pada tingkat dimana seseorang secara psikologis memihak kepada organisasinya dan pentingnya pekerjaan bagi gambaran dirinya. Ia menegaskan bahwa seseorang yang memiliki keterlibatan kerja yang tinggi dapat terstimulasi oleh pekerjaannya dan tenggelam dalam pekerjaannya.Robbins menambahkan bahwa karyawan yang memiliki tingkat keterlibatan yang tinggi sangat memihak dan benar-benar peduli dengan bidang pekerjaan yang mereka lakukan. Seseorang yang memiliki Job Involvement yang tinggi akan melebur dalam pekerjaan yang sedang ia 
lakukan. Tingkat keterlibatan kerja yang tinggi berhubungan dengan Organizational Citizenship Behavior dan performansi kerja. Sebagai tambahan, tingkat keterlibatan kerja yang tinggi dapat menurunkan jumlah ketidakhadiran karyawan (Robbins, 2009: 306).

Hiriyappa (2009) mendefinisikan keterlibatan kerja (Job Involvement) sebagai tingkat sampai sejauh mana individu mengidentifikasikan dirinya dengan pekerjaannya, secara aktif berpartisipasi di dalamnya, dan menganggap performansi yang dilakukannya penting untuk keberhargaan dirinya. Tingkat keterlibatan kerja yang tinggi akan menurunkan tingkat ketidakhadiran dan pengunduran diri karyawan dalam suatu organisasi. Sedangkan tingkat keterlibatan kerja yang rendah akan meningkatkan ketidakhadiran dan angka pengunduran diri yang lebih tinggi dalam suatu organisasi. Patchen (dalam Srivastava, 2005) menyatakan bahwa seseorang yang memiliki keterlibatan kerja (Job Involvement) yang tinggi akan menunjukkan perasaan solidaritas yang tinggi terhadap perusahaan dan mempunyai motivasi kerja internal yang tinggi. Individu akan memiliki keterlibatan kerja yang rendah jika ia memiliki motivasi kerja yang rendah dan merasa menyesal dengan pekerjaannya. Artinya, individu yang memiliki keterlibatan kerja yang rendah adalah individu yang memandang pekerjaan sebagai bagian yang tidak penting dalam hidupnya, memiliki rasa kurang bangga terhadap perusahaan, dan kurang berpartisipasi dan kurang puas dengan pekerjaannya. Berdasarkan dari definisi-definisi di atas maka dapat disimpulkan bahwa keterlibatan kerja (Job Involvement) merupakan komitmen seorang karyawan terhadap pekerjaannya yang ditandai dengan karyawan memiliki kepedulian yang tinggi terhadap pekerjaan dalam lingkungan kerjanya, serta keterlibatan kerja berhubungan langsung dengan Organizational Citizenship Behavior dalam menentukan kinerja. Dengan adanya perasaan terikat secara psikologis terhadap pekerjaan yang ia lakukan, maka karyawan akan merasa bahwa pekerjaanya sangat penting dalam kehidupan kerja dan mempunyai keyakinan kuat akan kemampuan dalam menyelesaikan masalah.

\section{Iklim Organisasi}

Iklim merupakan suatu konsep sistem yang dinamis, iklim seperti udara dalam ruangan yang mengitari dan mempengaruhi segala hal dalam ruangan tersebut. Iklim tidak dapat disentuh dan dilihat, tetapi iklim dapat dirasakan.

Organisasi adalah sebuah struktur sosial, yang didesain guna mengoordinasikan kegiatan dua orang atau lebih, melalui suatu pembagian kerja, dan hierarki otoritas, guna melaksanakan pencapaian tujuan umum tertentu (Winardi, 2008: 53). Langsung maupun 
tidak langsung oleh orang yang hidup dan bekerja ditempat tersebut yang mempengaruhi motivasi dan tingkah laku mereka (Denison, 2007). Organisasi cenderung menarik dan mempertahankan orang-orang yang sesuai dengan iklimnya, sehingga dalam tingkatan tertentu polanya akan langgeng. Apabila iklim dalam suatu tempat pada kontinum yang bergerak dari yang menyenangkan ke netral sampai yang tidak menyenangkan, iklim dapat menyenangkan apabila mereka melakukan sesuatu yang bermanfaat dan menimbulkan perasaan yang mampu menciptakan kepuasan kerja (Kelner, 2005).Secara tegas iklim organisasi membandingan kumpulan ilmu sosial secara tradisional dengan menggunakan metode kuantitatif, dimana fokus pada satu waktu tertentu (Denison, 2007).Dalam menganalisa iklim organisasi maka dibutuhkan analisa mengenai perasaan, emosi, dan mental individu (karyawan perorangan), grup (departemen, unit, dan program per area), dan keseluruhan organisasi. Analisa dapat menggunakan kuesioner, fokus grup ataupun interview (Schauber, 2007).

Iklim organisasi atau organizational climate menurut Davis \& Newstrom (2005: 123) adalah "the human environment within which an organization's employes do their work". Iklim organisasi adalah lingkungan dimana karyawan suatu organisasi melakukan pekerjaan mereka. Callahan dan Fleenor (2006:423), menyatakan bahwa iklim organisasi sebagai suatu gambaran atau deskripsi tentang bagaimana individu merasakan (experience) kultur organisasi. Iklim organisasi juga dapat digambarkan sebagai suatu kumpulan persepsi para anggota organisasi tentang karakteristik dan kualitas budaya organisasi. Sedangkan budaya organisasi itu sendiri didefinisikan sebagai pola dari berbagai nilai (value), sikap, keyakinan, asumsi, harapan, aktivitas, interaksi, norma dan sentimen yang dianut para anggota organisasi. Iklim organisasi tercermin dalam perasaan dan persepsi individu sedangkan budaya organisasi digambarkan sebagai underlying mechanism yang sebagian akan direfleksikan oleh iklim organisasi.Iklim organisasi menurut Owens (2007: 171) didefinisikan sebagai persepsi anggota organisasi yang merefleksikan norma, asumsi dan keyakinan yang dianut organisasi tersebut dan berbagai aspek yang termasuk dalam lingkungan tersebut.

Menurut Higgins (2005: 204-206) iklim organisasi didefinisikan sebagai suatu totalitas persepsi para karyawan termasuk manajer terhadap pekerjaan dan lingkungan sosialnya. Iklim organisasi (organizational climate) menurut James and Jones (Davidson, 2005:21) adalah : "Set of characteristics that describe an organization and that distinguish 
the organization from other organizations and influence the behavior of people in the organization.

\section{Kepuasan Kerja}

Kepuasan kerja merupakan sikap yang ditunjukan pegawai dalam menjalankan tugasnya terkait dengan harapannya dan kenyataan yang ada. Kepuasan kerja menurut Robbins (2007: 30) adalah "suatu sikap umum terhadap pekerjaan seseorang; selisih antara banyaknya ganjaran yang diterima seorang pekerja dan banyaknya yang mereka yakini seharusnya mereka terima". Selain itu Hasibuan (2007: 202) menyebutkan bahwa "kepuasan kerja adalah suatu sikap emosional yang menyenangkan dan mencintai pekerjaannya".

Definisi yang diungkapkan oleh Robbins dan Hasibuan di atas mengarahkan bahwa kepuasan kerja pegawai merupakan sikap emosional yang menunjukkan perasaan menyenangkan maupun tidak menyenangkan dari harapan yang seharusnya diterima pegawai dengan kenyataan yang ada. Perasaan yang timbul dari kepuasan kerja pegawai melibatkan beberapa aspek yang di antaranya adalah faktor internal pegawai yaitu, kemampuan, kesehatan, usia, jenis kelamin, motivasi, serta faktor eksternal pegawai yaitu, hubungan dengan rekan kerja, lingkungan dan kondisi kerja, jenis pekerjaan, mutu pengawasan, karateristik pekerjaan pemimpin.

Kepuasan kerja pegawai dalam suatu organisasi harus diciptakan sehingga pegawai meningkatkan kecintaan terhadap pekerjaannya. Menurut Martoyo (2005: 56) menyatakan "bila kepuasan kerja terjadi, maka pada umumnya tercermin pada perasaan karyawan terhadap pekerjaannya dan segala sesuatu yang dihadapi ataupun ditugaskan kepadanya di lingkungan kerjanya”. Kepuasan kerja anggota dalam organisasi akan menimbulakan kinerja yang tinggi, begitu pula sebaliknya. Salah satu teori kepuasan kerja adalah teori yang dikembangkan oleh Federick Herzberg yaitu teori dua faktor. Dari penelitian yang dilakukan Herzberg ditemukan terdapat dua faktor pendorong yang berkaitan dengan perasaan positif terhadap pekerjaan sehingga membawa kepuasan kerja, dan yang kedua adalah faktor yang dapat mengakibatkan ketidakpuasan kerja.

Kepuasan kerja adalah faktor primer yang berkaitan dengan pekerjaan itu sendiri, sedangkan ketidakpuasan berkaitan dengan memuaskan anggota organisasi dan menjaga mereka tetap dalam organisasi dan itu berkaitan dengan lingkungan dalam organisasi (dalam Hasanan, 2011: 1). Kepuasan kerja muncul didasari atas faktor-faktor tertentu. Faktor tersebut bisa berasal dari luar individu yang disebut faktor ekstrinsik dan faktor yang berasal 
dari dalam individu yang disebut faktor intrinsik. Menurut Mangkunegara (2007: 67)" faktor ekstrinsik yang menyebabkan timbulnya rasa tidak puas, yaitu administrasi dan kebijakan perusahaan, kualitas pengawasan, hubungan dengan pengawas, hubungan dengan subordinat, upah, keamanan kerja, kondisi kerja, dan status". Faktor intrinsik kepuasan kerja diungkapkan oleh Tampubulon (2005: 87) yaitu "faktor intrinsik yang menyebabkan timbulnya rasa puas atau tidak puas, antara lain: prestasi, pengakuan, tanggung jawab, kemajuan, pekerjaan itu sendiri, dan kemungkinan berkembang". Bilamana kedua faktor ini terpenuhi dalam diri individu, maka individu tersebut akan puas dan memunculkan sikap loyal serta menunjukkan kecintaanya terhadap pekerjaan. Namun, apabila faktor-faktor tersebut tidak terpenuhi, maka individu akan merasa tidak puas dan menunjukkan kinerja yang buruk dalam organisasi.

Kepuasan kerja merupakan suatu kondisi subjektif dari keadaan pribadi seseorang sehubungan dengan perasaan senang atau tidak senang dari hasil pekerjaannya. Orang yang merasa puas menurut Chaplin (2006: 433) diartikan sebagai suatu keadaan kesenangan dan kesejahteraan disebabkan karena orang tersebut telah mencapai satu tujuan atau sasaran. Menurut Robbins (2005: 170) kepuasan kerja adalah suatu sikap umum terhadap pekerjaan seseorang sebagai perbedaan antara banyaknya ganjaran yang diterima pekerja dengan banyaknya ganjaran yang diyakini seharusnya diterima. Werther (2005: 51) juga mengatakan bahwa kepuasan kerja sebagai suatu pemikiran dari karyawan mengenai seberapa jauh pekerjaanya secara keseluruhan mampu memuaskan kebutuhannya. Dengan kata lain kepuasan kerja akan dipengaruhi oleh terpenuhinya segala kebutuhan karyawan, jika kebutuhan dapat dipenuhi perusahaan maka karyawan akan puas dan sebaliknya jika kebutuhan tidak terpenuhi maka akan menimbulkan ketidakpuasan dalam bekerja. Sementara itu kepuasan kerja adalah sikap emosional yang menyenangkan dan mencintai pekerjaannya. Sikap ini dicerminkan oleh moral kerja, kedisiplinan dan prestasi kerja. Kepuasan kerja dinikmati dalam pekerjaan, luar pekerjaan, dan kombinasi dalam dan luar pekerjaan (Hasibuan, 2007 : 202).

Kepuasan kerja merupakan hasil keseluruhan dari derajat rasa suka atau tidak sukanya tenaga kerja terhadap berbagai aspek dari pekerjaannya. Dengan kata lain kepuasan mencerminkan sikap tenaga kerja terhadap pekerjaannya. Kepuasan kerja dipengaruhi oleh beberapa faktor yaitu karakteristik pekerjaan, gaji, penyeliaan, rekan-rekan sejawat yang menunjang dan kondisi kerja yang menunjang (Munandar, 2009:357). 


\section{Kinerja Pegawai}

Kinerja adalah tingkat keberhasilan dalam melaksanakan tugas, serta kemampuan untuk mencapai tujuan yang telah ditetapkan. Kinerja dikatakan baik dan sukses jika tujuan yang diinginkan dapat tercapai dengan baik (Gibson et.al., 2007:171). Kinerja karyawan adalah prestasi (hasil) kerja karyawan atau pegawai selama periode tertentu dibandingkan dengan berbagai kemungkinan (standar, target, atau kriteria) yang telah ditentukan terlebih dahulu dan disepakati bersama (Soeprihanto, 2007:7) Irawan dkk. (2007:11) yang dimaksud dengan kinerja (performance) adalah hasil kerja yang bersifat konkrit, dapat diukur, dan dapat diamati. Lebih lanjut dikatakan bahwa kinerja bersifat aktual (riil) sedang tujuan bersifat ideal. Hal senada dikemukakan Mangkunegara (2009:67), bahwa kinerja berasal dari kata job performance atau performance (prestasi kerja atau prestasi sesungguhnya yang dicapai oleh seseorang). Kinerja diartikan sebagai hasil kerja secara kualitas dan kuantitas yang dicapai oleh pegawai dalam melaksanakan tugasnya sesuai dengan tanggung jawab yang diberikan kepadanya.

Kinerja berarti (1) sesuatu yang dicapai, (2) prestasi yang diperhatikan, dan (3) kemampuan kerja. Salim dalam The Contemporary English-Indonesia Dictionary mengatakan, istilah kinerja (performance) digunakan bila seorang menjalankan suatu tugas atau proses dengan terampil sesuai dengan prosedur dan ketentuan yang ada (Salim, 2006:631). Dalam kajian manajemen kinerja berarti hasil dari sukses kerja seseorang atau sekelompok untuk mencapai sasaran-sasaran yang relevan (Kast dan Rozenweing, 2005:25).Dari uraian tersebut dapat dikemukakan bahwa kinerja (performance) dapat berupa hasil kerja, prestasi kerja, atau tingkat keberhasilan seseorang dalam tugas dan tanggung jawabnya yang diberikan kepadanya.

Timpe (2007:33) menyebutkan bahwa kinerja dipengaruhi oleh faktor-faktor internal dan eksternal. Kinerja individu akan baik jika dari faktor internal: memiliki kemampuan tinggi dan kerja keras, dan dari faktor eksternal: adanya pekerjaan mudah, nasib baik, bantuan dari rekan kerja, dan pimpinan yang baik. Jika tidak demikian halnya, maka kinerja individu adalah buruk. Pernyataan yang senada dikemukakan Griffin (2005:394-395), bahwa kinerja kerja ditentukan oleh tiga hal, yaitu kemampuan, keinginan, dan lingkungan. 


\section{METODOLOGI}

\section{Tempat Penelitian}

Menentukan tempat penelitian mempunyai maksud untuk mempersempit ruang lingkup penelitian dan juga ada beberpa aspek yang menjadi pertimbangan seperti daya jangkau peneliti dan sumber dana yang dimiliki. Dengan berbagai pertimbangan tersebut, maka lokasi penelitian ditetapkandi PT. XBatam.

\section{Metode Penelitian}

Pendekatan penelitian yang digunakan dalam penelitian ini adalah pendekatan kuantitatif, sementara jenis penelitiannya adalah survei sedangkan metodenya yakni deskriptif analitis dengan alat analisa data menggunakan regresi liner berganda. Data dikumpulkan melalui pengisian angket atau kuesioner. Melalui penelitian ini diharapkan dapat diketahui pengaruh pelatihan dan motivasi kerja karyawan terhadap kinerja karyawan tetap di bagian produksi parts pada PT X Batam. Penelitian dilakukan untuk memperoleh informasi tentang pengaruh karateristik pekerjaan, iklim organisasi dan kepuasan kerja terhadap kinerja karyawan. Mengacu kepada tujuan penelitian, maka penelitian ini bersifat deskriptif dan verifikatif.

Penelitian yang sifatnya deskriptif, bertujuan untuk mendeskripsikan karakteristik variabel yang diteliti secara empirik. Adapun penelitian yang sifatnya verifikatif, bertujuan untuk membuktikan kebenaran hipotesis penelitian yang diajukan melalui pengujian data lapangan. Sesuai dengan sifatnya, metode penelitian yang digunakan adalah eksplanatori (explanatory survey methods), yaitu metode bertujuan untuk menjelaskan hubungan kausal antara variabel-variabel melalui pengujian hipotesis. Proses pengumpulan data penelitian dilakukan secara tidak langsung, yaitu melalui penyebaran instrumen penelitian berupa angket.

Responden dalam penelitian ini adalah para pegawai/ aparatur inspektorat propinsi kepri berdasarkan kualifikasi Pendidikan. Informasi dan data penelitian yang berhasil dikumpulkan adalah data skala ordinal, yang kemudian untuk persyaratan pengolahan data yang menggunakan analisis Regresi Linier Berganda

\section{Populasi dan Penarikan Sampel}

Populasi dalam penelitian ini adalah karyawan tetap yang bekerja pada administrasi PT. X Batam yang berjumlah sebanyak 70 karyawan. Peneliti dalam penelitian ini tanpa melihat strata dan bidang tugas tertentu. Arikunto (dalam Riduwan, 2008: 210) 
mengemukakan bahwa untuk sekedar ancer-ancer apabila subjek kurang dari 100, maka lebih baik diambil semua, sehingga penelitiannya merupakan penelitian populasi. Oleh karena keterbatasan populasi maka semua anggota populasi dijadikan sampel penelitian sehingga penelitian ini menggunakan sampel jenuh yang pengambilannya dilakukan melalui teknik sensus.

\section{Instrumen dan Definisi Operasionalisasi Variabel}

Penggunaan definisi operasional (indicator empiric) untuk mengukur konsep, dipakai untuk menjawab permasalahan-permasalahan penelitian. Untuk mengukur suatu konsep, maka harus diukur adalah makna atau konsepsi dari konsep tersebut, yang harus diungkap lewat definisi yang jelas. Alat untuk mengukur makna dari suatu konsep adalah indikator empirik.

\section{Variabel Karakteristik Pekerjaan}

Karakteristik pekerjaan merupakan isi atau dimensi inti pekerjaan yang menggambarkan sifat-sifat tugas dan tanggung jawab yang ada dalam suatu pekerjaan. Variabel ini dapat diukur dengan indikator-indikator yang diungkapkan oleh Hackman dan Oldham, yaitu: variasi keterampilan, identifikasi tugas, signifikansi tugas, otonomi, dan umpan balik. Adapun kisi-kisi kuesioner dari variabel karakteristik pekerjaan dapat dilihat pada tabel di bawah ini:

\section{Tabel 2}

Kisi-Kisi Instrumen Variabel Karakteristik Pekerjaan

\begin{tabular}{|c|c|c|c|}
\hline Variabel & Indikator & Kisi-Kisi Kuesioner & Pengukuran \\
\hline $\begin{array}{l}\text { Eksogen: } \\
\text { Karakteristik } \\
\text { Pekerjaan } \\
\left(\mathrm{X}_{2}\right)\end{array}$ & $\begin{array}{l}\text { Signifikansi } \\
\text { Tugas }\end{array}$ & $\begin{array}{l}\text { 1. Jenis pekerjaan yang lakukan } \\
\text { memberikan kesempatan } \\
\text { menunjukkan kemampuan dan } \\
\text { keterampilan yang dimiliki. } \\
\text { 2. Jenis pekerjaan yang menjadi } \\
\text { tanggung jawab menawarkan } \\
\text { beragam tugas. } \\
\text { 3. Dapat melihat hasil pekerjaan } \\
\text { dalam kinerja kantor secara } \\
\text { keseluruhan. } \\
\text { 4. Mengetahui dengan jelas apa yang } \\
\text { diharapkan kantor dari pekerjaan } \\
\text { yang lakukan. } \\
\text { 5. Pekerjaan yang lakukan dinilai } \\
\text { penting (berarti) oleh pegawai } \\
\text { lainnya. } \\
\text { 6. Hasil pekerjaan berdampak pada } \\
\text { kemampuan kantor dalam meraih } \\
\text { sukses. } \\
\text { 7. Diberi keleluasaan merencanakan } \\
\text { pekerjaan yang akan dilakukan. } \\
\text { 8. Dalam penyelesaian tugas, }\end{array}$ & $\begin{array}{l}\text { Skala Likert } \\
1 \text { s/d } 5 \text { yang } \\
\text { merupakan } \\
\text { pendapat } \\
\text { Sangat Tidak } \\
\text { Setuju (STS) } \\
\text { sampai dengan } \\
\text { Sangat Setuju } \\
\text { (SS) dari } \\
\text { responden }\end{array}$ \\
\hline
\end{tabular}




\section{pendapat dan gagasan \\ diperhitungkan oleh rekan kerja dan atasan. \\ 9. Rekan kerja memberikan kritikan dan saran atas hasil kerja. \\ Umpan Balik \\ 10. Pimpinan meberikan kritik dan saran atas hasil kerja.}

\section{Variabel Iklim Organisasi}

Iklim organisasi didefinisikan sebagai persepsi anggota organisasi yang merefleksikan norma, asumsi dan keyakinan yang dianut organisasi tersebut dan berbagai aspek yang termasuk dalam lingkungan tersebut. Indikator-indikator untuk mengukur variabel iklim organisasi seperti yang diungkapkan oleh Litwin dan Stringer (1968: 81-82) meliputi: struktur, tanggung jawab, penghargaan, resiko, kehangatan/kekeluargaan, dukungan, standar, konflik, dan identitas. Adapun kisi-kisi kuesioner dari variabel iklim organisasi dapat dilihat pada tabel 3 .

\section{Tabel 3}

\section{Kisi-Kisi Instrumen Variabel Iklim Organisasi}

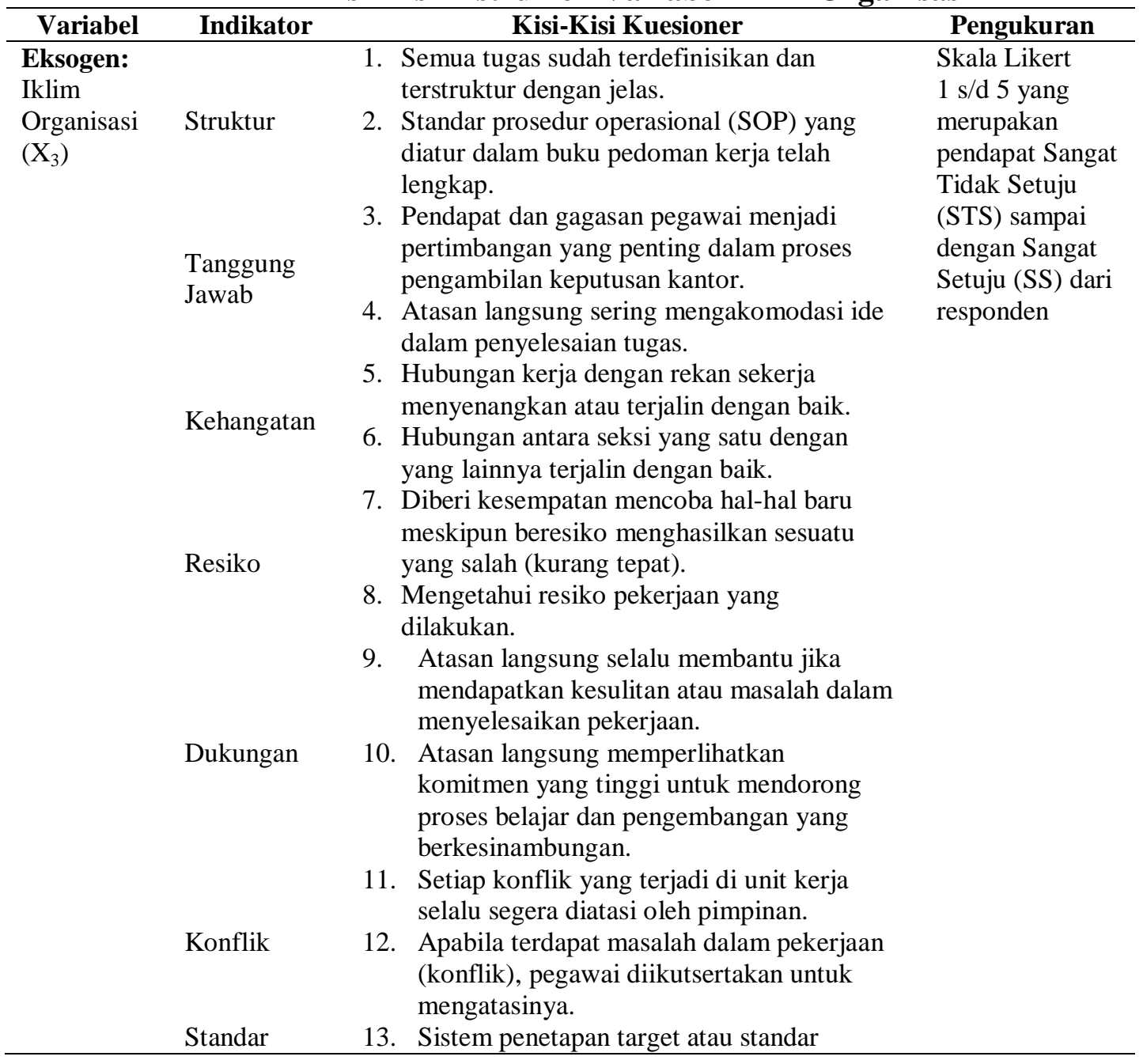




\begin{tabular}{|c|c|c|}
\hline & 14. & $\begin{array}{l}\text { penilaian kinerja sudah memperhitungkan } \\
\text { kemampuan pegawai. } \\
\text { Kantor memberikan kesempatan berkarier } \\
\text { bagi pegawai yang memiliki prestasi } \\
\text { tinggi. }\end{array}$ \\
\hline & 15. & $\begin{array}{l}\text { Kantor memberikan penghargaan untuk } \\
\text { pegawai yang berprestasi. }\end{array}$ \\
\hline $\begin{array}{l}\text { Imbalan dan } \\
\text { Sanksi }\end{array}$ & 16. & $\begin{array}{l}\text { Pegawai yang melanggar akan dikenakan } \\
\text { sanksi yang tegas sesuai dengan ketentuan } \\
\text { yang berlaku. }\end{array}$ \\
\hline Iden & 17. & $\begin{array}{l}\text { Mengetahui dan memahami dengan jelas } \\
\text { misi dan visi institusi (kantor). }\end{array}$ \\
\hline Organisasi & 18. & $\begin{array}{l}\text { Memahami dengan baik tujuan dan sasaran } \\
\text { srategis institusi (kantor). }\end{array}$ \\
\hline
\end{tabular}

\section{Variabel Kepuasan Kerja Pegawai}

Kepuasan kerja merupakan suatu kondisi subjektif dari keadaan pribadi seseorang sehubungan dengan perasaan senang atau tidak senang dari hasil pekerjaannya. Orang yang merasa puas diartikan sebagai suatu keadaan kesenangan dan kesejahteraan disebabkan karena orang tersebut telah mencapai satu tujuan atau sasaran. Indikator-indikator untuk mengukur variabel kepuasan kerja sebagaimana diungkapkan oleh Schermerhorn (1995: 45), meliputi: pekerjaan itu sendiri, penyelia, teman sekerja, dan promosi. Adapun kisi-kisi kuesioner dari variabel kepuasan kerja pegawai dapat dilihat pada Tabel 4 berikut ini:

\section{Tabel 4}

Kisi-Kisi Instrumen Variabel kepuasan kerja

\begin{tabular}{|c|c|c|c|}
\hline Variabel & Indikator & Kisi-Kisi Kuesioner & Pengukuran \\
\hline $\begin{array}{l}\text { Intervening: } \\
\text { Kepuasan } \\
\text { Kerja } \\
\left(\mathrm{X}_{4}\right)\end{array}$ & Rekan Kerja & $\begin{array}{l}\text { 1. Pekerjaan sangat menarik dan } \\
\text { menyenangkan. } \\
\text { 2. Pekerjaan sesuai dengan latar } \\
\text { belakang pendidikan. } \\
\text { 3. Pimpinan/atasan memberikan } \\
\text { keleluasaan mengaktualisasikan } \\
\text { potensi diri. } \\
\text { 4. Pimpinan/atasan } \\
\text { mengembangkan pola } \\
\text { komunikasi dua arah. } \\
\text { 5. Pimpinan memberikan } \\
\text { penghargaan atas prestasi kerja. } \\
\text { 6. Rekan kerja memberikan } \\
\text { dukungan yang berarti. } \\
\text { 7. Rekan kerja mau berbagi } \\
\text { informasi tehadap hal-hal yang } \\
\text { baru. } \\
\text { 8. Rekan kerja mau memberi } \\
\text { bantuan jika dibutuhkan. } \\
\text { 9. Kantor memberlakukan kriteria } \\
\text { promosi jabatan untuk semua } \\
\text { pegawai tanpa pilih kasih. } \\
\text { 10. Kantor memberikan kesempatan } \\
\text { promosi kepada semua pegawai. }\end{array}$ & $\begin{array}{l}\text { Skala Likert } \\
1 \text { s/d } 5 \text { yang } \\
\text { merupakan } \\
\text { pendapat Sangat } \\
\text { Tidak Setuju } \\
\text { (STS) sampai } \\
\text { dengan Sangat } \\
\text { Setuju (SS) dari } \\
\text { responden }\end{array}$ \\
\hline
\end{tabular}




\section{Variabel Kinerja Pegawai}

Kinerja pegawai merupakan bagian yang sangat penting dalam suatu organisasi untuk mengukur sejauh mana pelaksanaan tugas dan tanggung jawab telah memenuhi harapan yang telah ditetapkan. Ada beberapa indikator untuk mengukur kinerja sebagaimana diungkapkan oleh Cascio (dalam Karjantoro, 2004:27), yaitu: hasil kerja, perilaku, kompetensi, dan potensi. Adapun kisi-kisi kuesioner dari variabel kinerja pegawai dapat dilihat pada tabel 3.6 berikut ini:

\section{Tabel 5}

Kisi-Kisi Instrumen Variabel Kinerja Pegawai

\begin{tabular}{|c|c|c|c|}
\hline \multirow[b]{2}{*}{\begin{tabular}{l}
\multicolumn{1}{c}{ Variabel } \\
Endogen: \\
Kinerja \\
Pegawai \\
$\left(\mathrm{X}_{5}\right)$
\end{tabular}} & Indikator & Kisi-Kisi Kuesioner & Pengukuran \\
\hline & Kompetensi & $\begin{array}{l}\text { 1. Mampu menyelesaikan tugas yang } \\
\text { diberikan kepada tepat pada } \\
\text { waktunya. } \\
\text { 2. Mampu menyelesaikan tugas } \\
\text { secara mandiri. } \\
\text { 3. Mampu menyelesaikan tugas } \\
\text { dengan baik dan dapat diterima } \\
\text { rekan kerja dan pimpinan. } \\
\text { 4. Mampu menunjukan kedisiplinan } \\
\text { yang baik dalam bekerja. } \\
\text { 5. Tidak menyealahgunakan } \\
\text { wewenang serta tanggung jawab } \\
\text { yang diberikan. } \\
\text { 6. Selalu sopan dalam berprilaku, } \\
\text { baik kepada sesama rekan kerja } \\
\text { maupun dengan pimpinan. } \\
\text { 7. Mampu mengembangkan } \\
\text { kreativitas dalam menyelesaikan } \\
\text { tugas. } \\
\text { 8. Mampu memahami tugas-tugas } \\
\text { yang diberikan tanpa banyak } \\
\text { bantuan yang diberikan. } \\
\text { 9. Mampu membantu rekan sekerja } \\
\text { dengan ide dan kreativitas yang } \\
\text { dimiliki. } \\
\text { 10. Memiliki jiwa kepemimpinan } \\
\text { dalam memotivasi dan memberikan } \\
\text { semangat kerja pada rekan kerja } \\
\text { dalam bekerja. } \\
\text { 11. Mampu menunjukkan loyalitas dan } \\
\text { dedikasi yang tinggi terhadap } \\
\text { kantor. } \\
\text { 12. Mampu bekerja sama dengan rekan } \\
\text { sekerja dalam menyelasaikan } \\
\text { pekerjaan. }\end{array}$ & $\begin{array}{l}\text { Skala Likert } \\
1 \text { s/d } 5 \text { yang } \\
\text { merupakan } \\
\text { pendapat Sangat } \\
\text { Tidak Setuju } \\
\text { (STS) sampai } \\
\text { dengan Sangat } \\
\text { Setuju (SS) dari } \\
\text { responden }\end{array}$ \\
\hline
\end{tabular}

\section{Metode Analisis Data}

1. Analisis Regresi Linier Berganda 
Analisis ini digunakan untuk mengetahui seberapa besar pengaruh variabel bebas yaitu : Motivasi (X1) dan Pelatihan (X2) terhadap variabel terikatnya yaitu kinerja Karyawan (Y).

Persamaan regresi linier berganda adalah sebagai berikut (Ghozali : 2005):

$\mathrm{Y}=\mathrm{a}+\mathrm{b} 1 \mathrm{X} 1+\mathrm{b} 2 \mathrm{X} 2+\mathrm{e}$

2. Pengujian Hipotesis

a. Uji Signifikansi Simultan (Uji Statistik F)

F-test untuk menguji apabila variabel bebas (independen) secara simultan mempunyai pengaruh yang signifikan atau tidak signifikan terhadap variabel terikat (dependen).

Untuk menganalisa apakah hipotesis diterima atau ditolak, maka dilihat terlebih dahulu bagaimana hipotesisnya.

1. $\mathrm{H} 0: \mathrm{b} 1, \mathrm{~b} 2=0$ berarti tidak ada pengaruh yang signifikan antara motivasi dan pelatihan terhadap Kinerja karyawan.

2. Ha : minimal salah satu $b \neq 0$ berarti ada pengaruh yang signifikan antara motivasi dan pelatihan terhadap kinerja karyawan.

Kriteria penolakan dan penerimaan hipotesis adalah sebagai berikut:

1. Tolak Ho jika nilai probabilitas $\mathrm{F} \leq$ taraf signifikan sebesar 0,05 (Sig. $\leq \alpha$ $0,05)$

2. Terima Ho jika nilai probabilitas $\mathrm{F}>$ taraf signifikan sebesar 0,05 (Sig. $>\alpha$ $0,05)$

b. Analisis Koefisien Determinasi $\left(\mathrm{R}^{2}\right)$

Koefisien Determinan $\left(\mathrm{R}^{2}\right)$ pada intinya mengukur seberapa jauh kemampuan model dalam menerangkan variabel dependen. Nilai koefisien determinasi adalah antara nol sampai satu $\left(0<\mathrm{R}^{2}<1\right)$. Nilai $\mathrm{R}^{2}$ yang kecil berarti kemampuan variabel-variabel independen dalam menjelaskan variabel dependen amat terbatas. Nilai yang mendekati satu berarti variabel-variabel independen memberikan hampir semua informasi yang dibutuhkan untuk memprediksi variasi variabel dependen.

c. Uji Signifikansi Pengaruh Parsial (Uji t)

Uji t dilakukan untuk menguji masing-masing variabel bebas (X) dengan variable terikat $(\mathrm{Y})$, uji t ini dilakukan untuk mengetahui seberapa jauh 
masing-masing variable motivasi dan pelatihan kerja mempengaruhi kinerja karyawan. Langkah-langkah pengujiannya adalah:

1. Menentukan formulasi hipotesis

Ho $: b=0$ artinya, tidak ada pengaruh dari masing-masing variabel bebas $(\mathrm{X})$ terhadap variabel terikat $(\mathrm{Y})$

Ha $: b \neq 0$ artinya, ada pengaruh dari masing-masing variabel bebas $(X)$ terhadap variabel terikat (Y).

3. Kriteria penolakan dan penerimaan hipotesis adalah sebagai berikut:

Tolak Ho jika nilai probabilitas $\mathrm{t} \leq$ taraf signifikan sebesar 0,05 (Sig. $\leq \alpha$ $0,05)$.

Terima Ho jika nilai probabilitas $\mathrm{t}>$ taraf signifikan sebesar 0,05 (Sig.> $\alpha 0,05$

\section{PEMBAHASAN}

\section{Uji Persyaratan Analisis}

Uji persyaratan analisis dalam penelitian ini menggunakan uji instrumen (reliabilitas dan validitas) uji normalitas dengan menggunakan Kolmogorov-Smirnov, uji linearitas, dan pengujian hipotesis.

\section{Hasil Uji Instrumen}

Pengujian instrumen penelitian dilakukan melalui uji reliabilitas dan uji validititas dengan bantuan software SPSS 16.0. Sebagaimana yang disyaratkan oleh Nunally (dalam Ghozali, 2001), instrumen penelitian dinyatakan reliabel apabila memiliki nilai Cronbach's Alpha $\geq$ 0,60 Sedangkan Validitas instrumen menurut Sugiyono (2002: 109) dinyatakan valid apabila koefisien korelasi setiap butir-butir instrumen $\geq 0,30$ dari semua variabel yg diuji validitas butir pertanyaannya valid dan realibel.

\section{Uji Asumsi Klasik}

\section{Uji Normalitas}

Pengujian normalitas dilakukan dengan menggunakan perhitungan uji KolmogorovSmirnov. Pedoman pengambilan keputusan dengan uji Kolmogorov-Smirnov tentang data tersebut mendekati atau berdistribusi normal dapat dilihat dari nilai Asymp Sig. (2-tailed), yaitu apabila Asymp Sig. (2-tailed) >0,05, maka distribusi data adalah normal. Sedangkan apabila nilai Asymp Sig. (2-tailed) < 0,05 maka distibusi data adalah tidak normal. Hasil uji normalitas dengan menggunakan metode Kolmogorov-Smirnov dapat dilihat pada Tabel 6. 
Tabel 6

Hasil Uji Normalitas

\begin{tabular}{clccc}
\hline No. & Data Variabel & $\begin{array}{c}\text { Nilai Asymp Sig. } \\
(2 \text {-tailed }) \\
\text { (atau nilai } \mathrm{p})\end{array}$ & $\begin{array}{c}\text { Kriteria } \\
\text { Jika Nilai } \mathrm{p}>0,05, \\
\text { Terima Ho. }\end{array}$ & Kesimpulan \\
\hline 1. & Karteristik Pekerjaan & 0.192 & $\mathrm{p}>0,05$ & Normal \\
2. & Iklim Organisasi & 0.112 & $\mathrm{p}>0,05$ & Normal \\
3. & Kepuasan Kerja & 0.404 & $\mathrm{p}>0,05$ & Normal \\
4. & Kinerja Pegawai & 0.641 & $\mathrm{p}>0,05$ & Normal \\
\hline
\end{tabular}

Sumber: Data Primer yang diolah, 2015

Dasar pengambilan keputusan:

Ho. : Data sampel berasal dari populasi berdistribusi normal

Ha. : Data sampel berasal dari populasi bukan berdistribusi normal

Berdasarkan hasil uji normalitas tersebut tampak bahwa nilai Asyimp Sig. (2-tailed) pada semua kelompok rancangan penelitian ternyata lebih besar dari nilai probabilitas (p) yaitu 0.05. Dengan demikian dapat disimpulkan bahwa data sampel penelitian ini berasal dari populasi yang berdistribusi normal.

\section{Uji Multikolinieritas}

Uji multikolinieritas digunakan untuk menguji apakah model regresi ditemukan adanya korelasi antara variabel bebas, dimana model regresi yang baik seharusnya tidak terjadi korelasi antara variabel bebas. Cara untuk menilainya adalah dengan melihat nilai faktor infasi varian (VIF) yang tidak melebihi 4 atau 5 (Hitnes dan Montgomery dalam Rumengan dkk, 2010).

\begin{tabular}{|c|c|c|c|c|c|c|c|c|}
\hline & & & $\begin{array}{l}\text { Tabe } \\
\text { Coeff }\end{array}$ & $\begin{array}{l}6 \text { Multikolin } \\
\text { icients }^{\mathrm{a}}\end{array}$ & eritas & & & \\
\hline & & $\begin{array}{r}\text { Unsta } \\
\text { Coe }\end{array}$ & $\begin{array}{l}\text { lardized } \\
\text { cients }\end{array}$ & $\begin{array}{l}\text { Standardized } \\
\text { Coefficients }\end{array}$ & & & $\begin{array}{r}\text { Colline } \\
\text { Statist }\end{array}$ & \\
\hline & & $\mathrm{B}$ & Std. Error & Beta & $\mathrm{t}$ & Sig. & Tolerance & VIF \\
\hline 1 & (Constant) & 19.803 & 2.812 & & 7.043 & .000 & & \\
\hline & $\begin{array}{l}\text { Karateristik } \\
\text { Pekerjaan }\end{array}$ & -.018 & .128 & -.013 & -.137 & .891 & .686 & 1.457 \\
\hline & Iklim & .562 & .106 & .793 & 5.321 & .000 & .286 & 3.496 \\
\hline & $\begin{array}{l}\text { Urganisasi } \\
\text { Kepuasan } \\
\text { Kerja }\end{array}$ & -.022 & .114 & -.029 & -.192 & .848 & .270 & 3.708 \\
\hline
\end{tabular}

a. Dependent Variable: Kinerja

Berdasarkan Tabel 6 ketiga variabel independen yakni motivasi dan pelatihan memiliki nilai VIF dalam batas toleransi yang ditentukan (tidak melebihi 4 atau 5), sehingga tidak terjadi multikolinieritas dalam variabel independen penelitiaan ini. 


\section{Uji Heteroskedastisitas}

Uji heteroskedastisitas digunakan Untuk menguji apakah dalam model regresi terjadi ketidaksamaan varians dari residual satu pengamatan ke pengamatan yang lainnya. Berikut hasil uji heteroskedastisitas dengan menggunakan pendekatan grafik.

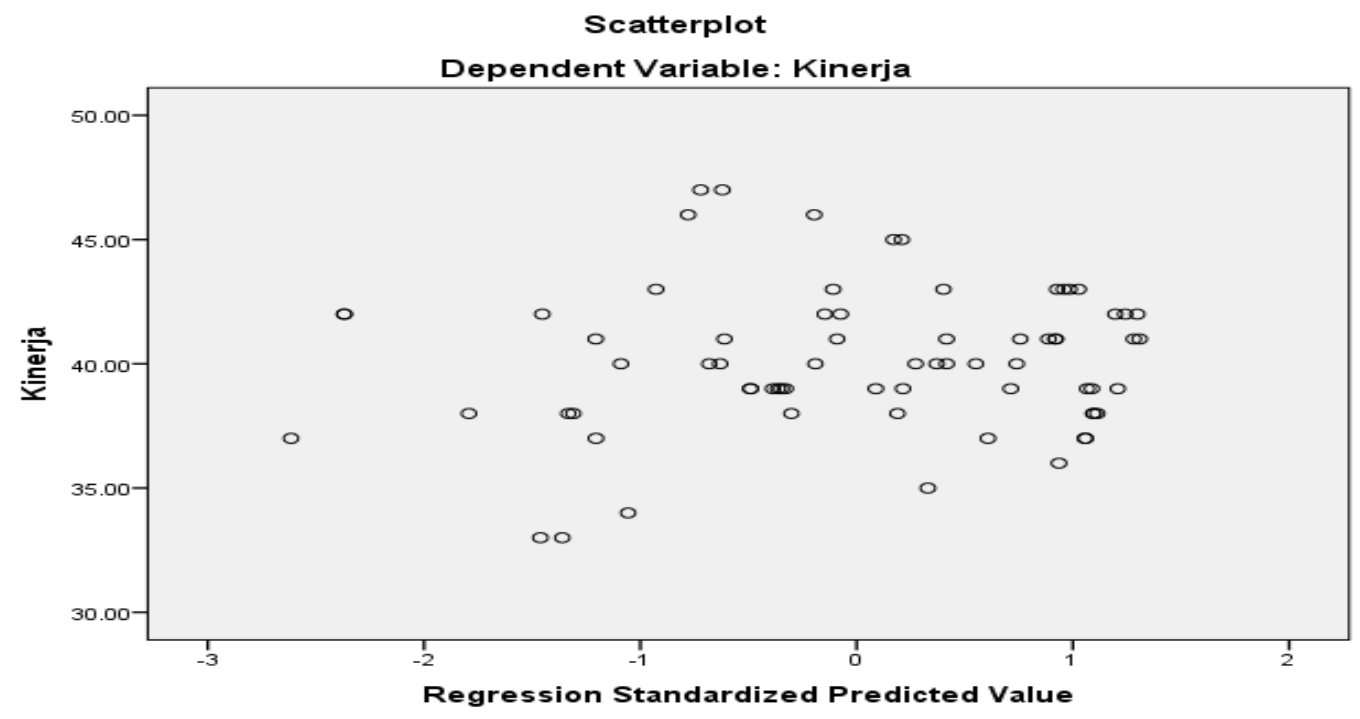

Gambar 1

\section{Heteroskedastisitas}

Dari grafik Scatter plot diatas, terlihat titik menyebar secara acak tidak membentuk sebuah pola tertentu yang jelas, tersebar diatas baik di bawah angka 0 pada sumbu Y. Hal ini berarti tidak terjadi heteroskedastisitas pada model regresi layak dipakai untuk memprediksi Kinerja, berdasarkan masukan variabel independennya.

\section{Analisis Regresi}

Analisis regresi pada dasarnya adalah studi mengenai ketergantungan variabel dependen (Kinerja) dengan variabel independen ( motivasi dan pelatihan), dengan tujuan untuk memprediksi perubahan nilai variabel terikat akibat pengaruh dari nilai variabel bebas.

Tabel 7 Koefisien Regresi Coefficients $^{\mathrm{a}}$

\begin{tabular}{|c|c|c|c|c|c|c|}
\hline \multirow[b]{2}{*}{ Model } & & \multicolumn{2}{|c|}{$\begin{array}{l}\text { Unstandardized } \\
\text { Coefficients }\end{array}$} & $\begin{array}{l}\text { Standardized } \\
\text { Coefficients }\end{array}$ & \multirow[b]{2}{*}{$\mathrm{t}$} & \multirow[b]{2}{*}{ Sig. } \\
\hline & & B & Std. Error & Beta & & \\
\hline 1 & (Constant) & 19.803 & 2.812 & & 7.043 & .000 \\
\hline & Karateristik & -.018 & .128 & -.013 & -.137 & .891 \\
\hline & Pekerjaan & & & & & \\
\hline & Iklim Organisasi & .562 & .106 & .793 & 5.321 & .000 \\
\hline & Kepuasan Kerja & -.022 & .114 & -.029 & -.192 & .848 \\
\hline
\end{tabular}

a. Dependent Variable: Kinerja

Hasil pada Tabel $7 \mathrm{~d}$ iatas dapat di tuliskan dalam model persamaan regresi liniernya sebagai berikut: 
$\mathrm{Y}=19.803-0.018 \mathrm{X} 1+0.5626 \mathrm{X} 2-0.022 \mathrm{X} 3$

Maksud persamaan diatas adalah:

1. Nilai konstan (a) untuk persamaan regresi adalah 19.803 dengan parameter positif. Hal ini berarti bahwa apabila karateristik pekerjaan (X1), Iklim organisasi (X2) ,Kepuasan Kerja (X3) sama dengan nol, maka Kinerja karyawan bagian produksi Parts PT. Snepac Batam sebesar 19.803 dengan asumsi variabel lain adalah konstan.

2. Koefisien Karateristik pekerjaan (X1) bernilai negative, hal ini berarti jika karateristik pekerjaan ditingkatkan 1 satuan maka kinerja akan mengalami penurunan sebesar 0,018.

3. Koefisien Iklim organisasi (X2) bernilai positif, hal ini berarti jika Iklim organisasi ditingkatkan 1 satuan maka Kinerja akan mengalami kenaikan sebesar 0,562.

4. Koefisien Kepuasan Kerja (X3) bernilai negative, hal ini berarti jika Kepuasan Kerja ditingkatkan 1 satuan maka kinerja akan mengalami penurunan sebesar 0,022.

Hal ini menunjukkan bahwa peningkatan pada variabel Karateristik Pekerjaan dan Kepuasan Kerja akan menurunkan variabel Kinerja demikian untuk peningkatan variabel Iklim Organisasi akan menaikkan variabel Kinerja.

\section{Koefisien Determinasi (R-Square)}

Nilai R-square adalah untuk melihat bagaimana variasi nilai variabel terikat dipengaruhi oleh variasi nilai variabel bebas (Rumengan dkk, 2010)

\section{Tabel 8 Koefisien Determinasi ( R-Square )} Model Summary

\begin{tabular}{|c|c|c|c|c|c|c|c|c|c|}
\hline \multirow[b]{3}{*}{$\begin{array}{l}\text { Mode } \\
1\end{array}$} & \multirow[b]{3}{*}{$\mathrm{R}$} & \multirow[b]{3}{*}{$\begin{array}{c}\mathrm{R} \\
\text { Square }\end{array}$} & \multirow[b]{3}{*}{$\begin{array}{l}\text { Adjusted R } \\
\text { Square }\end{array}$} & \multirow{3}{*}{$\begin{array}{l}\text { Std. Error } \\
\text { of the } \\
\text { Estimate }\end{array}$} & \multirow{2}{*}{\multicolumn{4}{|c|}{ Change Statistics }} & \multirow[b]{3}{*}{$\begin{array}{c}\text { Sig. F } \\
\text { Change }\end{array}$} \\
\hline & & & & & & & & & \\
\hline & & & & & $\begin{array}{l}\text { R Square } \\
\text { Change }\end{array}$ & F Change & df1 & $\mathrm{df} 2$ & \\
\hline 1 & $.762^{\mathrm{a}}$ & .580 & .561 & 1.93222 & .580 & 30.433 & 3 & 66 & .000 \\
\hline
\end{tabular}

Hasil koefisien berganda adalah $.762^{\mathrm{a}}$, sedangkan nilai R square adalah 0.580 atau $58 \%$, hasil ini mengindikasikan bahwa 58\% variabel kinerja (Y) dapat dijelaskan oleh variabel karateristik pekerjaan (X1) dan iklim organisasi (X2) serta kepuasan kerja (X3), sisanya sebesar $(100-52)=48 \%$ dipengaruhi oleh variabel lain yang tidak diteliti dalam penelitian ini.

\section{Analisis Temuan Peneliti}

Dari hasil penelitian terlihat bahwa semua variabel bebas (Karateristik Pekerjaan, Iklim Organisasi dan Kepuasan Kerja) mempunyai pengaruh terhadap variabel Y (Kinerja). Untuk lebih jelasnya hasil analisa dan pengujian yang telah dilakukan, penjelasannya sebagai berikut:

1. Terdapat pengaruh yang signifikan variabel X1 (Karateristik Pekerjaan) terhadap 
variabel Y (Kinerja) yang ditunjukkan oleh nilai signifikan $0.001<0.005$ dimana koefisien regresi variabel motivasi sebesar -0,018, dimana Koefisien Karateristik pekerjaan (X1) bernilai negative, hal ini berarti jika variabel karateristik pekerjaan mengalami peningkatan sebesar 1 satuan maka varibel kinerja akan mengalami penurunan sebesar 0,018 .

2. Terdapat pengaruh yang signifikan variabel X2 (Iklim Organisasi) terhadap variabel Y (Kinerja) yang ditunjukkan oleh nilai signifikan $0.000<0.005$ dimana koefisien regresi variabel motivasi sebesar +0.562 , dimana Koefisien Iklim Organisasi (X2) bernilai positive, hal ini berarti jika Variabel Iklim Organisasi mengalami peningkatan sebesar 1 satuan maka variabel Kinerja akan mengalami peningkatan juga sebesar 0,562 .

3. Terdapat pengaruh yang signifikan variabel X3 (Kepuasan Kerja) terhadap variabel Y (Kinerja) yang ditunjukkan oleh nilai signifikan $0.000<0.005$ dimana koefisien regresi variabel motivasi sebesar -0,022, dimana Koefisien Kepuasan Kerja (X3) bernilai negative, hal ini berarti jika Variabel Kepuasan Kerja mengalami peningkatan sebesar 1 satuan maka akan menurunkan variabel Kinerja sebesar 0,022.

4. Karateristik Pekerjaan (X1), Iklim Organisasi (X2), Kepuasan Kerja(X3) secara simultan mempunyai pengaruh yang signifikan terhadap Kinerja (Y) pada karyawan PT. Snepac Batam dimana Hasil pengujian dengan SPSS variabel independen secara bersama-sama diperoleh nilai $\mathrm{F}$ hitung $=30.433$ dengan nilai probabilitas $\mathrm{F}$ (sig) adalah sebesar 0,000 (sig.0,000< 00,05 ).

5. Nilai koefisien berganda adalah $.762^{\mathrm{a}}$, sedangkan nilai $\mathrm{R}$ square adalah 0.580 atau $58 \%$, hasil ini mengindikasikan bahwa 58\% variabel kinerja (Y) dapat dijelaskan oleh variabel karateristik pekerjaan (X1) dan iklim organisasi (X2) serta kepuasan kerja $(\mathrm{X} 3)$, sisanya sebesar $(100-52)=48 \%$ dipengaruhi oleh variabel lain yang tidak diteliti dalam penelitian ini.

Dalam Penelitian ini dapat dikemukakan bahwa seluruh variabel mempunyai pengaruh yang signifikan dimana nilai koefisien dari karateristik pekerjaan dan kepuasan kerja bernilai negative ini mengartikan bahwa pada PT. X Batam terjadi fenomena yang belum maksimalnya menyangkut dengan variabel karateristik pekerjaan dan kepuasan kerja artinya perlu adanya usaha dari pihak manajemen untuk menaikkan atau melakukan penanganan khusus yg berkaitan dengan job description atau karataristik pekerjaan dan kepuasaan kerja 
sehingga kinerja yg diharapkan dapat optimal sesuai dengan tujuan organisasi sedangkan iklim organisasi telah tercipta atau terlaksana dengan baik di PT. X Batam hal ini ditandai dengan nilai koefisien yg positive jadi secara keseluruhan hasil penelitian ini menggambarkan bahwa variabel karateritik pekerjaan dan kepuasan kerja mengalami penurunan sedangkan variabel Iklim organisasi mengalami kenaikan, hal ini akan sangat berpengaruh terhadap kinerja karyawan yang tercipta di PT. X Batam. sesungguhnya karakteristik pekerjaan berpengaruh secara signifikan terhadap kepuasan kerja pegawai. Karakteristik pekerjaan merupakan dimensi inti yang menggambarkan sifat atau inti dari pekerjaan. Nilai Koefisien dari Karateristik dan Kepuasan kerja negative artinya karateristik pekerjaan pada PT. X Batam sangat mempengaruhi persepsi karyawan yang negatif terhadap pekerjaanya sehingga melahirkan tidak puas dalam bekerja hal ini diakibatkan oleh dalam bekerja seseorang mengalami kejenuhan akibat pekerjaan yang monoton, tidak sesuai dengan latar belakang pendidikan atau keahlian serta tidak adanya keleluasan dalam bekerja, dan sebagainya sehingga menimbulkan menurunnya kinerja dalam bekerja. sebaliknya iklim organisasi berpengaruh langsung signifikan positif terhadap kinerja dimana persepsi para karyawan terhadap kualitas lingkungan fisik, fsikis dan sosial yang ada dalam lingkungan organisasi telah mampu menciptakan hubungan yang saling menghargai, adanya keterbukaan antara atasan dengan bawahan, dan berjalannya komunikasi antara sesama pegawai akan memberikan kenyamanan dan akan meningkatkan kinerja bagi orang-orang yang ada di dalamnya, namun dalam uji serempak karateristik pekerjaan,iklim organisasi serta kepuasan kerja dalam penelitian ini berpengaruh secara signifikan artinya penggabungan ketiga variabel ini masih memberikan nilai positive bagi peningkatan kinerja di PT. X Batam.

\section{Keterbatasan Penelitian}

Penelitian ini memiliki beberapa keterbatasan-keterbatasan yang kemungkinan dapat menimbulkan gangguan terhadap hasil penelitian. Keterbatasan-keterbatasan tersebut antara lain: Data penelitian ini dihasilkan dari instrumen yg dibangun dari teori kemudian dikembangkan menjadi butir pertanyaan yang mendasarkan pada jawaban responden dalam bentuk skala likert.

Hal ini menimbulkan banyak masalah diantaranya factor psikologis responden dalam menjawab questioner sehingga mengandung unsur subjektif yg sangat tinggi. Disamping itu penelitian ini didasarkan pada metode survei melalui kuisioner, peneliti tidak melakukan wawancara, sehingga kesimpulan yang dikemukakan hanya berdasarkan pada data yang 
terkumpul melalui tabulasi yg dikelola menggunakan alat analisa data path analisis jalur sehingga antara peneliti dengan responden tidak berinteraksi secara langsung atau tidak tercipta hubungan serta interaksi secara mendalam dalam memaknai penelitian untuk pengembangan teori dimasa yg akan datang.

\section{KESIMPULANDAN SARAN}

\section{Kesimpulan}

Berdasarkan hasil analisis data, pengujian hipotesis dan hasil temuan deskriptif dari kuesioner dengan jumlah populasi karyawan PT. X Batam sebanyak 70 responden, maka dapat disimpulkan sebagai berikut:

a) Hasil pengujian menunjukkan terdapat signifikan karakteristik pekerjaan terhadap kinerja pada PT. X Batam.

b) Hasil pengujian menunjukkan terdapat yang signifikan signifikan antara iklim organisasi terhadap kinerja pada PT. X Batam.

c) Hasil pengujian menunjukkan terdapat pengaruh yang signifikan kepuasan kerja terhadap kinerja pada PT. X Batam.

d) Hasil pengujian menunjukkan karateristik pekerjaan,iklim organisasi dan kepuasan kerja berpengaruh secara signifikan terhadap kinerja pada PT. X Batam.

\section{Saran}

1. Pimpinan PT. $\mathrm{X}$ hendaknya dapat mendisain pekerjaan untuk membantu pekerja merasakan pekerjaan yang lebih bermakna dan bernilai. Disain tentang keragaman, identitas tugas, kebermaknaan tugas, kewenangan bertugas, dan umpan balik.

2. Perlu dilakukan upaya-upaya untuk meningkatkan kepuasan kerja kerja dimana diarahkan pada bagaimana melakukan atau memanfaatkan sesuatu agar mencerminkan prinsip efektifitas dan efisiensi. Sesuatu dikatakan efektif bila pemanfaatan berbagai aspek benar-benar tepat sasaran sesuai dengan tujuan yang diinginkan. Dikatakan efisien jika apa yang dilakukan mempertimbangkan aspek biaya, sarana prasarana, sumber daya (manusia dan material), dan waktu sehemat mungkin. Kepuasan Kerja kerja adalah pendayagunaan sumber daya manusia secara efektif dan efesien, ketepatan atau keserasian penggunaan metode atau cara kerja dibandingkan dengan alat atau waktu yang tersedia, dalam rangka mencapai tujuan. Ukuran pokoknya adalah penyelesaian volume dan beban kerja yang tepat pada waktunya, dengan menggunakan sumber daya manusia secara minimal. 
3. Penelitian ini diharapkan dapat mendorong untuk dilakukan penelitian-penelitian berikutnya pada bidang manajemen sumber daya manusia dengan menggunakan variabel-variabel lain yang belum dimasukan dalam penelitian ini, misalnya kompensasi, budaya kerja dan kepemimpinan dll.

\section{REFERENSI}

Al Rasyid, Harun. 2008. Teknik Penarikan Sampel dan Penyusunan Skala, Program Pasca Sarjana. Bandung.

Arikunto, Suharsimi, 2007. Dasar-Dasar Evaluasi Pendidikan (Edisi Revisi). Jakarta: Bumi Aksara

Ashrahenny dan Ratnasari, Sri Langgeng. 2016. Pengaruh Gaya Kepemimpinan Dan Komunikasi Terhadap Kinerja Karyawan PT. Hi-Test (Laboratory Of Mechanical Testing). Zona Manajemen ISSN 2087-6998. Fakultas Ekonomi Universitas Batam. Volume 8, Nomor 3, Desember 2016. Hal. 1-10.

Azwar, Saifuddin. 2007. Penyusunan Skala Psikolog. Yogyakarta: Pustaka Pelajar.

Bernardin, John. 2007. Human Resource Managemen. New York: McGraw-Hill

Bradberry, Travis. 2008. The Personality Code. Ahli Bahasa: Dede Nurdin. Yogyakarta: Wangun Printika.

Callahan, R.E. and Fleenor, C.P. 2007. Managing Human Relation: Concept \& Practices. USA: Merill Publishing Company.

Cherniss, Cary and Goleman, D.2007. The Emotionally Intelligent Workplace. San Francisco: Jossey-Bass.

Claver, E., Llopis, J., \& Gasco, J.L. 2007. A corporate culture pattern to manage business ethics, International Journal of Value-Based Management. 15.

Darmayanti dan Ratnasari, Sri Langgeng. 2016. Pengaruh Gaya Kepemimpinan Dan Fasilitas Kerja Terhadap Kinerja Pegawai Pada Kantor Camat Batam Kota. Zona Manajemen ISSN 2087-6998. Fakultas Ekonomi Universitas Batam. Volume 8, Nomor 1, April 2016. Hal. 11-18

Davis, K dan Newstroom John. W. 2007. Human Behavior at Work : Organizational Behavior. Seven Edition. New York: Mc. Grow-Hill, Inc.

Dessler, G. 2007. Manajemen Sumber Daya Manusia. Jakarta: PT. Prehallindo.

Efendi, Vivi Kusuma dan Ratnasari, Sri Langgeng. 2014. Pengaruh Kepemimpinan, Komunikasi, Dan Motivasi Kerja Terhadap Kinerja Guru SMA Di Kecamatan Batam 
Kota Batam. Zona Manajemen ISSN 2087-6998. Fakultas Ekonomi Universitas Batam. Volume 6, Nomor 3, Desember 2014. Hal. 1-13

Flippo, Edwin B. 2008. Manajemen Personalia. Terjemahan Agus Dharma. Jakarta: Erlangga.

Furtwengler, Dale. 2007. Penilaian Kinerja. Yogyakarta: Andi.

Gomes, Faustino Cardoso. 2005. Manajemen Sumber Daya Manusia. Yogyakarta: Andi Offset.

Gibson, James L., Ivancevich, John M. dan Donnely, James H., Jr. 2007. Organizations: Behavior, Structure, Processes, USA: Richard D. Irwin.

Goleman, D. 2005. Working With Emotional Intelegence: Kecerdasan Emosi Untuk Mencapai Puncak Prestasi. Jakarta: PT. Gramedia Pustaka Utama.

__, 2006. Emotional Intelligence: Kecerdasan Emosional, Mengapa EI Lebih Penting dari IQ, ahli bahasa T. Hermaya. Jakarta: PT. Gramedia Pustaka Utama.

—_, 2007. Emotional Intelligence Untuk Mencapai Puncak Prestasi, Alih Bahasa : Alex Tri K.W. Jakarta: PT. Gramedia Pustaka Utama.

Greenberg, Jerald dan Baron, Robert A. 2007. Behavior in Organizations: Understanding and Managing The Human Side Of Wor. New Jersey: Prentice Hall International.

Hackman, J.R., and Oldham, R.G.. 2007. Work Design. Wesley Publishing company, Inc.

Hamalik, Oemar. 2008. Kurikulum dan Pembelajaran. Jakarta: Bumi Aksara.

Handoko, T. Hani. 2007. Manajemen Personalia dan Sumber Daya Manusia. Yogyakarta: BPFE.

Hasibuan. M. 2007. Manajemen Sumber Daya Manusia. Jakarta: Bumi Aksara Jakarta.

Hasibuan, H. Malayu S.P. 2008. Organisasi dan Motivasi Dasar Peningkatan Produktivitas.Jakarta: Bumi Aksara.

Ilyas, Yaslis. 2008. Kinerja: Teori, Penilaian, dan Penelitian. Depok: Pusat Kajian Ekonomi Kesehatan FKMUI.

Irianto, Jusuf, 2009. Tema-tema Pokok Manajemen Sumber Daya Manusia. Surabaya: Insan Cendekia.

Ivancevich, John M. \& Matteson, Michael T. (2008), Organizational Behavior and Management, $6^{\text {th }}$ ed.. New York: McGraw-Hill

Karjantoro, Handoko.2007. Mengelola Kinerja: Suatu Tinjauan Praktis. Manajemen Usahawan Indonesia No.07/TH XXXIII Juli 2004, hal 24. Jakarta: LM-UI 
Kolb, D.A., J.M. Osland and I.M. Rubin. 2007. Organizational Behavior. New Jersey : Prentice Hall, Englewood Cliffs.

Kuncoro, Mudrajad. 2009. Metode Kuantitatif (Teori dan Aplikasi untuk Bisnis dan Ekonomi). Yogyakarta: AMP YKPN

Lilo, Christianto dan Ratnasari, Sri Langgeng. 2015. Pengaruh Gaya Kepemimpinan Dan Kompensasi Terhadap Kinerja Karyawan Pada PT. Supreme Nusapermai Development. Zona Manajerial. ISSN 2087-7331. Volume 7 Nomor 2, Agustus 2015. Hal. 50-69. Fakultas Ekonomi Universitas Batam

Murwanto, Didik dan Ratnasari, Sri Langgeng. 2016. Pengaruh Kompensasi dan Gaya Kepemimpinan Terhadap Motivasi Kerja Karyawan PT. Fast Precision Manufacturing Indonesia. Zona Manajerial. ISSN 2087-7331. Volume 8 Nomor 1, April 2016. Hal. 1-

12. Fakultas Ekonomi Universitas Batam

Luthans, Fred. 2008. Organizational Behavio. Boston: McGraw Hill.

Mangkunegara, A.A. Anwar Prabu. 2005. Perilaku dan Budaya Organisasi. Bandung: Refika Aditama.

Morgan, Weisz \& Schopler. 2009. Introduction to Psychology, New Jersey: McGraw-Hill: Book Company.

Munandar, Ashar Sunyoto. 2007. Psikologi Industri dan Organisasi. Jakarta: Universitas Indonesia.

Newstrom, John W. 2007. Organizational Behavior, Boston: McGraw Hill.

Ostroff, C., 2007, "The Relationship Between Satisfaction Attitudes and Performance on Organizational Level Analysis", Journal of Applied Psychology, Vol. 77, No. 6, p. 963974.

Prawirosentono, Suyadi. 2009. Manajemen Sumber Daya Manusia: Kebijakan Kinerja Karyawan. Yogyakarta: BPFE UGM.

Randoy, T., \& Nielsen. J. 2007. Company performance, corporate governance, and CEO Compensation in Norway and Sweden. Journal of Management and Governance. 6.

Ratnasari, Sri Langgeng, Budiman Christiananta, dan Anis Eliyana. 202. Pengaruh Komitmen Organisasional dan Budaya Organisasi Terhadap Kepuasan serta Prestasi Kerja Dosen Tetap Yayasan Perguruan Tinggi Swasta di Provinsi Kepulauan Riau. Jurnal Akuntansi dan Manajemen (JAM) ISSN: 0853-1269, STIE YKPN Yogyakarta, 
Vol. 23, No.1, April 2012, TERAKREDITASI SK DIRJEN DIKTI NO.:64a/DIKTI/Kep./2010 Tanggal 1 Nopember 2010. Hal 51-60

Riduwan. 2008. Skala Pengukuran Variabel-Variabel Penelitian. Bandung: Alfabeta

Robbin, Stephen P. 2007. Organization Behavior, New Jersey: Englewood Cliffs.

Schein, E. H. 2007. Organizational Culture and Leadership. San Fransico, CA: Joersey Bass. Schemoerhorn, et.al. 2006. Managing Organizational Behaviour. New York: John Willey \& Sons, Inc.

Sedarmayanti. 2007. Manajemen Sumber Daya Manusia (reformasi Birokrasi dan Manajemen PNS), ed 1. Bandung: Refika Aditama.

Siagian, Sondang P. 2009. Manajemen Sumber Daya Manusia. Jakarta: CV. Haji Masagung.

Stein, Steven J and Howard E. Book, 2008. Ledakan EQ: 15 Prinsip Dasar Kecerdasan Emosional Meraih Sukses. Terjemahan Trinanda Rainy Januarsari \& Yudhi Martanto. Jakarta: Kaifa.

Suprihanto, J. 2009. Penilaian Kinerja dan Pengembangan Karyawan. Yogyakarta: BPFE.

Suryani, Luh Ketut. 2010. Atasi Masalah dengan Kemampuan Spiritual Anda. Jakarta: PT. Intisari

Tosi, L.R. Rizzo, and S. Caroll. 2007. Managing Organizational Behavior. New York: McGraw Hill, Inc.

Tulus, Moh. Agus. 2009. Manajemen Sumber Daya Manusia. Jakarta: PT. Gramedia Pustaka Utama.

Van Rooy, D. L., \& Visvesvaran, C. 2007. Emotional Intelligence: A Meta-Analytic Investigation of Predictive Validity and Nomological Net. Journal of Vocational Behaviour .65, 71-95.

Weisinger, H. 2008. Emotional Intelligence at Work. San Francisco: Jossey-Bass Inc.

Winardi, J. (2009). Motivasi dan Pemotivasian dalam Manajemen. Jakarta: PT. Raja Grafindo Persada. 